SYMBOLAE PHILOLOGORUM POSNANIENSIUM GRAECAE ET LATINAE XXXI/2 • 2021

pp. 43-58. ISSN 0302-7384, ISSN (Online) 2720-2305

DOI: $10.14746 / \mathrm{sppgl} .2021 . X X X I .2 .6$

ISHA GAMLATH

University of Kelaniya, Sri Lanka

e-mail: ishagam@gmail.com

\title{
THE PHILOSOPHER'S DIET IN PORPHYRY'S DE ABSTINENTIA: CHARACTERIZING A HISTORICAL LEGACY OF MINIMALISM IN FOOD CONSUMPTION
}

\begin{abstract}
Gamlath Isha, The Philosopher's Diet in Porphyry's De Abstinentia: Characterizing a Historical Legacy of Minimalism in Food Consumption (Dieta filozofa $w$ dziele Porfiriusza „De Abstinentia”. Charakterystyka historycznego dziedzictwa minimalizmu w konsumpcji pokarmów).
\end{abstract}

A component as the historical legacy of food consumption in traditional Greek and Roman culture has served in shaping an advanced stage of minimalism in Porphyry of Tyre's De Abstinentia.

Keywords: historical legacy; food consumption; minimalism; Porphyry

\section{A HISTORICAL LEGACY OF FOOD CONSUMPTION: MINIMALISM AND EXTRAVAGANCE}

The history of food consumption, whether as the history of diet or historical narratives of diet, is one of the key nuclei of the history of human civilization. ${ }^{1}$ Diet in Greco-Roman antiquity, as a complex subject located in an equally complex web of dietary diversity, has certainly been the focus of recent scholarly academia. ${ }^{2}$ Diet, in Greco-Roman antiquity, it has been argued, facilitates the construction of shared culinary identities in many ways. ${ }^{3}$ Apart from this identity there seems to be two poles of culinary habits as minimalism and extravagance.

\footnotetext{
${ }^{1}$ My sincere thanks go the reviewer who had offered some valuable suggestions. I dedicate this article to my beloved father, Prof. Sucharitha Gamlath on his $8^{\text {th }}$ death anniversary.

${ }^{2}$ Dalby 1996; Olson, Sens 2000; Beer 2010; Gorman and Gorman 2014.

${ }^{3}$ Notario 2015: 583. The identity is most obvious among specific sub-cultural groups, such as savages (Notario 2015: 584) and counter-cultural groups, such as Cynics (Notario 2015: 586).
} 


\section{MINIMALISM}

Minimalism was commonplace in the Archaic and Classical periods while also it was an ideal attached to mos maiorum and the broader Republican tradition. Minimalism was sometimes interpreted as "self-sufficiency" which after all, was often held as closely linked to one's "poverty", and Greece, writes Herodotus, "always had poverty as its companion" (Histories, 7.102). Minimalism, as "self-sufficiency", becomes more marked in the social scene of the early Roman Empire condemning Neronian luxury. ${ }^{4}$ Minimalism is a characteristic component of the Greek cultural tradition, in terms of not only food but also clothing and general living standards:

Out of a limited agriculture rises a simple material culture: a simple diet (mostly vegetariangrain, olives, figs, wine), simple dress (strips of woolen or goat-hair cloth [sakkos] wrapped in various ways about the body; strips of leather tied round the feet), and uncomplicated architecture prevail throughout the archaic and classical periods. Athletes exercise naked, and even among the upper classes who could afford otherwise, ostentatious jewelry and clothing were not standard fare. ${ }^{5}$

Minimalism, which is apparent in the standard Greek diet, in all historical periods, does not seem to have been changed - at least drastically. The staple diet of the majority, in the Classical period, was simple and consisted mostly of natural foods:

The majority of ancient peoples were compelled to survive on a limited number of staples. Evidence seems to suggest that the most important component of this diet was cereal. While it might be imprudent to make generalizations, the principal grain was barley in Greek territories, whereas there appears a marked preference within Roman culture for wheat. ${ }^{6}$

Meat and fish were both featured more prominently in ancient texts than fruit and vegetables, yet they formed a minor part of the ancient diet. ${ }^{7}$ The primarily cereal-based diet in the Greek and Roman world have been supplanted by accounts of an extraordinarily diverse diet, ranging from various kinds of meat, fowl, and marine resources to vegetables, fruits, nuts, pulses, cereals, spices and condiments, derived through farming, stock rearing, and hunting, or through importation of fresh, salted, or dried foods while supplemented with honey, eggs, dairy products, wine, and olive oil. ${ }^{8}$ Factors such as weather and economy which required strategic

${ }^{4}$ Brenk 2002-3: 80.

${ }^{5}$ Desmond 2005: 2.

${ }^{6}$ Beer 2010: 19. The basis for the division of choice for barley in the east and wheat in the west seems to have been either "taste" or the alleged Roman desire to maintain distance from what for them was an "inferior culture."

${ }^{7}$ Beer 2010: 24.

${ }^{8}$ Lagia 2015: 121. 
devices for more production and proper storage have been viewed as contributing to the development of an "involuntary dietary restriction" - a limitation in consuming foods. "Involuntary" though, the restriction of consuming certain food items does not seem to have created a too drastic distinction in the dietary practices of the majority. Boeotia and Thessaly had a reputation for gluttony. But this gluttony was not, however, for imported products but for home grown (local) products. ${ }^{10}$ The athlete's gluttony, outside the athlete's sportsmanship, excellence and strength, was also a fairly well-known dietary experience. ${ }^{11}$

Measures were applied for promoting minimalism, such as sumptuary regulation in Sparta. Sumptuary rules attracted the attention of many writers of the $1^{\text {st }}$ and $2^{\text {nd }}$ centuries $C E$, as a way to revive early Republican virtues that were neglected or forgotten. ${ }^{12}$ Roman sumptuary rules imposed on extravagant consumption in the Late Republic prevented the elite from involving in lavish dinners and thereby heading for moral decline. They were devoted to limiting the amount of cash to be spent on banquets as unlimited aristocratic competition, that were perceived as harmful to the society. ${ }^{13}$ The ideal of Romanitas, in the Late Republic, heightened the modest and frugal life of the typical Roman farming community, so say Cato and Varro. ${ }^{14}$ Disregard for ancestral customs was perceived to be the cause of moral as well as political and economic downturn during the Empire. ${ }^{15}$ The Romans of the Republic attached importance to the land, not trade or conquest, and not just for food but also as a source of wealth. ${ }^{16}$ One way to express the ideal of the Roman farmer is to eat produce from one's own lands or at least not from too far away. ${ }^{17}$ Frugality was a characteristic attitude to wealth among Rome's ancestral aristocracy and the people as a whole. ${ }^{18}$ Legislated frugality was widespread in pre-modern societies and ancient Rome was no exception. ${ }^{19}$

By the Classical period, however, theoretical debates begin to emerge on the character of a healthy diet. ${ }^{20}$ A notion of "primitive dietetics" develops after the $5^{\text {th }} \mathrm{c}$. BCE. ${ }^{21}$ Once established and respected as vital for human life, the notion of a healthy diet - an extension of the significance of health for human

\footnotetext{
${ }^{9}$ Beer 2010: 11 .

${ }^{10}$ Dalby 2003: 57.

${ }^{11}$ On the athlete's gluttony and Heraklean aspects of athletics: Bazant 1982: 129-131.

${ }^{12}$ Beer 2010: 21.

${ }^{13}$ Beer 2010: 101-15.

${ }^{14}$ Beerden 2018: 515 .

${ }^{15}$ Gildenhard, Viglietti 2020: 2.

${ }^{16}$ Beerden 2018: 515.

${ }^{17}$ Beerden 2018: 515.

${ }^{18}$ Gildenhard, Viglietti 2020: 1.

${ }^{19}$ Gildenhard, Viglietti 2020: 25.

${ }^{20}$ Totelin 2009: 133.

${ }^{21}$ Totelin 2009: 133-134.
} 
life - survived in antiquity "more or less unchallenged." ${ }^{22}$ The athlete's health, for example, both spiritual and physical, was held in high esteem in traditional Greek and Roman culture. ${ }^{23}$

A tradition of food consumption signaling dietary diversity, as opposed to minimalism, begins to gain ground as the Old Oligarch and Pericles bring to notice the pleasures of enjoying luxury items..$^{24}$ Before the $4^{\text {th }} \mathrm{c}$. BCE, luxurious foods were mostly associated with foreigners such as the Persians. This did not mean that the exhibition of luxury was entirely absent from the scene as is obvious from the presence of the symposium, the origins of which were associated with the leisured aristocratic class of elite Homeric warriors. ${ }^{25}$ It is interesting to note that luxury, its presence and indulgence, was often viewed as characterizing "feminity, the quality of which possessed negative connotations, associated with physical weakness and lack of moral fiber: an inability to practice self-control. ${ }^{, 26}$ Closely associating the tradition of luxury food consumption was fleshiness which became known as a positive characteristic of the rich ruler in Hellenistic art. The ancient idea of "fat" was often synonymous with richness, prosperity or fertility, and "thin" often corresponded to poverty and weak, feeble bodies. ${ }^{27}$ Interestingly, on the other hand, an attraction for thinness, instead of fatness, begins to circulate in the later Republic. ${ }^{28}$

\section{EXTRAVAGANCE}

By the $4^{\text {th }} \mathrm{c}$. BCE the symposium becomes a venue for intellectual aesthetic discussion while also for a "luxurious aristocratic banquet permeated by the "principle of pleasure." 29 By the $4^{\text {th }}$ c. BCE luxury dining in Greek society begins to coincide with Alexander's conquests of the east and the rapid influx of foreign commodity into Hellenistic cities which had its effect on specific elite groups, the royalty for example, while a more broadly-based Greek population seems to have participated in Hellenistic sympotic culture. ${ }^{30}$ The development of cookery and gastronomy begins to be established with the circulation of cookbooks by the late Classical period and the $4^{\text {th }} \mathrm{c}$. BCE. ${ }^{31}$ Athenaeus' Deipnosophistae is

\footnotetext{
${ }^{22}$ Hynek 2015: 17.

${ }^{23}$ For a comprehensive discussion, see Clark 2005: 216-229.

${ }^{24}$ Braund 1994: 41-42.

${ }^{25}$ Wecowski 2014: 4; Burton 1992: 232.

${ }^{26}$ Beer 2010: 103 .

${ }^{27}$ For more, see Bradley 2011: 1-41.

${ }^{28}$ Beer 2010: 35.

${ }^{29}$ Wecowski 2014: 3.

${ }^{30}$ Burton 1992: 234.

${ }^{31}$ Notario 2013: 178 .
} 
an interesting source of recipes while also of the arts of dining in the ancient Mediterranean. The Cynic rejection of new dishes marked their parallel rejection of the socio-cultural background of the elitist cuisine and all its messages and discourses concerning comfort, pleasure, and general distinction. ${ }^{32}$

Discourses on luxury in antiquity always originate with questions of social status. ${ }^{33}$ Most Roman writers of the early Empire connect corruption with wealth and luxury. ${ }^{34}$ Some compiled catalogues of Roman luxury - Pliny reflecting and Petronius transforming. ${ }^{35}$ By the $1^{\text {st }} \mathrm{c}$. BCE most provinces were stripped of wealth to supply the lusts of Rome. ${ }^{36}$ The culinary madness and whims of Roman emperors, a perfect display of the continuity of tradition of extravagance food consumption, has been the focus of a collection of biographies, such as those of Elagabalus (Historia Augusta, 2.18-19) and Gaius Caligula (Gaius Caligula, 37).

\section{PORPHYRY'S EXPOSURE TO SOURCES OF A HISTORICAL LEGACY OF A MINIMAL DIET: MYTH AND PRE-HISTORY, RITUAL AND PHILOSOPHY}

As was traced, a historical legacy of food consumption progresses, in Greek and Roman culture, often fluctuating between minimalism and extravagance. This legacy seems to have motivated Porphyry of Tyre, an eminent polymath well-versed in the diverse dietary habits of Greeks and non-Greeks, who was very much concerned with introducing in De Abstinentia a kind of dietary minimalism for the philosopher, in the form of a meat-free diet. ${ }^{37}$ In De Abstinentia Porphyry is defending a "vegetarian life style that excluded ordinary social and civic commitments." 38 Porphyry is also motivating "moral and soteriological consequences for those who wish to live a philosophical life and assimilate themselves to divinity." 39 Porphyry's introduction of a meat free diet for the philosopher was in line with traditional Greek and Roman culture while also an older philosophical tradition. Porphyry's discussion of the relevance of a nonmeat diet is more than an attempt to improve the living standard and behavior of the philosopher. It is more than an alternative proposition on how to live, in opposition to the dominant lavish lifestyle among the Greek and Roman elites of the Hellenistic period and the early centuries CE. It is also more than an account

\footnotetext{
${ }^{32}$ Notario 2015: 173-182.

${ }^{33}$ Beer 2010: 103 .

${ }^{34}$ Gorman and Gorman 2014: 3.

${ }^{35}$ Dalby 2000: 11 .

${ }^{36}$ Dalby 2000: 12 .

${ }^{37}$ Hereafter referred to as De Abst.

${ }^{38}$ Clark 2007: 13.

${ }^{39}$ Marx-Wolf 2016: 15.
} 
of the type of nutrition needed for the purpose of intellectual pursuit. It is a specialized commentary of the relevance of a minimal diet for the philosopher and this diet seems to be in line with a tradition of minimalism in Greek and Roman culture as opposed to a tradition of extravagance.

Porphyry's immediate target is Firmus Castricius who reverted to the way to the Divine by embracing a meat diet whether for "health and strength," (1.2.1), "lack of control," or "longing for gourmet gluttony" (1.2.3). He remembers how Firmus Castricius acknowledged "that the fleshless diet contributes to health and to a suitable endurance of hard work in philosophy" (1.2.1). In order to convince Firmus Castricius of the validity of a fleshless diet Porphyry recommends minimalism, and in doing it seems that Porphyry presents an alternative proposition on how to live, in opposition to the dominant lavish lifestyle among the Greek and Roman elites. He explains the historical and philosophical significance of a meat free diet. More conspicuously, Porphyry suggests a minimal diet with special emphasis on abstention from meat and blood sacrifice. This outline has been assessed for its ascetic implications ${ }^{40}$ This outline, as an argument for the practice of vegetarianism, has been noted for its ethnic identity. ${ }^{41}$ Next, its philosophical content for promoting a ritualized salvation. ${ }^{42}$ Still further, for its athletic component in terms of the efficacy of the metaphor of the Olympic athlete. ${ }^{43}$ Porphyry's defense of bloodless sacrifice in De Abst. has been noted as "disordering of kinship relations," a "demonization of blood sacrifice." ${ }^{45}$ Porphyry shares the early Christian daemonological belief that animal sacrifice "placates the gluttonous desires of evil daemons and cultic practitioners stand in danger of daemonic pollution." 46

When Porphyry proposes a minimal diet - a diet free from meat - in De Abst., he seems to profess knowledge of a long-standing legacy of minimalism where dietary habits were concerned. More profusely, Porphyry seems to be in the forefront in extending this legacy to his philosophical discourse when he takes into account its applicability for the philosopher. Within the context of the availability of luxury foods that could be paraded competitively as evidence of social status and prestige, and as luxury continued to be an effective element in the perceived lifestyle of, for example, the Julio-Claudians, it is not easy to assess precisely how this legacy of minimalism survived in philosophical discourses more so in Porphyry. A hint of this legacy is discernable in the manner of its representation in myth and pre-history, ritual and in specific intellectual circles.

\footnotetext{
${ }^{40}$ Townsend 2011: 214-231; Dombrowski 1987: 774-791; Meredith 1976: 324.

${ }^{41}$ Johnson 2013: 193-195; Schott 2005: 277-314; O’Meara 1982: 5-25; Clark 1999: 122-132.

${ }^{42}$ DePalma 2001: 521-528; Clark 2007: 13-27.

${ }^{43}$ Finn Op 2009: 9; Gamlath 2018: 49-66; Osek 2020: 233-247.

${ }^{44}$ Townsend 2013: 221.

${ }^{45}$ Marx Wolf 2010: 496

${ }^{46}$ Proctor 2014: 426.
} 


\section{MYTH AND PRE-HISTORY}

Greco-Roman culture indicates the observation of the mean in all its efforts so that removal of excess, if not minimalism, was appreciated in several domains, one of which was Greek myth. Myth, after all, has its own legacy as a "carrier of memory about the old times and the beginnings of civilization," while also it is an "expression of present-day values and a way to justify the current situation." The Greeks were so inspired by ideals of "simplicity" and "good old days" that the personification of these ideals was celebrated in the myth of Apheleia. A categorical development of an idyllic and beatific minimalism habitually associates the myth of the Golden Age, a paradigmatic age of simple existence and especially of a simple diet free from meat. ${ }^{48}$ Porphyry gives priority to the myth of the Golden Age, when he writes, on the authority of Empedocles, that the mythical golden race lived on a simple and very specially, a meatless diet and that the philosopher should "imitate" the inhabitants of the Golden Age:

What then shall we do? you ask, O man? We shall imitate the race of gold, we shall imitate those who have been liberated. Aidôs and Nemesis and Dikê associated with the golden race because they were satisfied with the fruits of the earth, fruits that for them the corn-giving earth bore of itself in abundance. (De Abst. 3.27.10)

A few accounts, such as the descriptions of Theophrastus' On Piety (ca. 320 BCE) and Dicaearchus' Life in Greece (ca. 300 BCE) are a testimony of simple existence and simple diet of pre-historical Greeks. ${ }^{49}$ On the authority of Dicaearchus, Porphyry writes that the way of life of pre-historical Greeks was close to that of the golden race, such as the early Greeks, who consumed food, sparingly and frugally:

They ate no food which was too strong for their nature to digest, but food with which their nature could cope; they took no more than a moderate amount, because of availability, and usually less than was sufficient, because of scarcity. (4.2.4)

Porphyry writes that a pristine innocence reigned in this age, above all other ages, whether historical or mythical:

Commenting on this, Dicaearchus says that was what life in the age of Kronos was like, if we are to accept that it happened and is not just a pointless story, but to reject the unduly mythical and reduce it to natural principle based on reason. Everything grew spontaneously: that is

\footnotetext{
${ }^{47}$ Ceglarska 2018: 350 .

${ }^{48}$ The myth has been treated extensively, to name a few: Plato, Pindar, Empedocles, Varro, Cicero, Virgil, Horace, Ovid and Seneca.

${ }^{49}$ Both works are lost now except a few fragments preserved mostly in Porphyry's De Abst. book two (Theophrastus fr. 584A Fortenbaugh) and book four (Dicaearchus fr. 56A Mirhady).
} 
reasonable, because people were making no provision at all, as they did not yet have the art of farming or any other. (4.2.3)

This early period of life, Porphyry writes, was free from such practices as war and violence to animals and such attitudes as injustice: "There was no war, because injustice had been expelled: war, and aggression towards each other, came in later, at the same time as injustice towards animals" (4.2.9).

Porphyry writes further that the ancients abstained from slaughtering animals:

Expounding the ancient way of life of Greece, he says that the ancients were born close to the gods: they were best in nature and lived the best kind of life, so as to be reckoned a race of gold in comparison with those of the present day who are made from base and valueless matter; and they killed no animate being. (4.2.1)

The tradition of consuming a simple diet, Porphyry writes, on the authority of Theophrastus, extends to pre-historic Greece, before the formation of the poleis, when the "earth produced trees before animals, and grasses, that germinate annually, long before trees" (2.2.2). This was when people consumed meatless foods as fruits (2.5.6), vegetables (2.6.1), honey and olive oil (2.6.4) and bread (2.7.1).

Porphyry records of legislators who favored minimalism. Xenokrates, on the authority of Hermippus' On the Legislators, writes that the legendary legislator Triptolemos banned injury to animals (4.22.2) while Drakon encouraged bloodless sacrifice (4.22.7). On the authority of Plutarch, Porphyry records that ancient Greek legislators, such as Lycurgus, inaugurated a nonluxury program promoting minimalism in life and diet. Porphyry describes that Lycurgus reduced one's property by introducing an "ownership of land bearing seventy bushels of barley for a man, twelve for a woman, and comparable amounts of fresh produce" (2.4.1) because "he thought this much food would suffice for adequate strength and health, and that they would need nothing else" (2.4.2). The Laconian drinking-cup, for example, was made so as to "conceal its color from sight the unpleasant appearance of water that is drunk of necessity, and its rim blocked and held back the mud so that the liquid reached the mouth in a purer state" (2.4.7). There certainly were other ways of "expelling luxury from Sparta," (2.4.3) one of which was the inauguration of common meals:

so that people came together to dine on fixed rations of grain and side-dishes which were common to all; they did not eat their meal at home, reclining on expensive couches with tables, being fattened in the dark, like an animal delicacy, at the hands of craftsmen and cooks, and destroying their bodies together with their characters by yielding them to every appetite and to a surfeit which requires long sleeps, hot baths, much rest and a kind of daily sick-nursing. $(2.4 .1)$ 


\section{RITUAL}

Ritual was a component for promoting minimalism. Ritual abstention from specific foods such as meat was permitted "largely to demarcate sacred places and times, to mediate a safe entry into, or communication with, the sacred realm of the gods." "Whether "periodic" or "permanent," such abstention bore strong implications of "self-sufficiency."

Given religious dynamics of the Platonists of the $3^{\text {rd }} \mathrm{c}$. CE, the focus on the soul's liberation through means of a taboo on meat and bloodless sacrifice becomes prominent in Roman sources from the Augustan period onwards. ${ }^{52}$ Ritual abstention from meat, which becomes fairly strong in the Platonist circles, encouraged the imitation of the Pythagorean way of life on account of its representation of ancient realities, including social practices, styles of life, ways of thought. ${ }^{53}$ Still further, this imitation, with a strong emphasis on dietary restriction, merged with various prohibitions on clothing, conduct and activities and ritual prescriptions. ${ }^{54}$ The ritual of abstention from meat, as both vegetarianism and bloodless sacrifice, blends into Porphyry's description of the Pythagoreans: "The Pythagoreans, following this tradition, abstained from animal-eating all their lives, and when they did assign some animal to the gods as an offering in place of themselves, they ate only that, but continued to live for truth, not touching the others" (2.28.2).

\section{INTELLECTUAL CIRCLES}

The imitation of "Pythagoras" or the "Pythagorean way of life," which perpetuated askesis merges not merely as ritual abstinence from meat and blood sacrifice - but more profusely, as a "mode of life" - stimulated an ethical perspective of perfecting one's self. Askesis (training), as the way to attain arête (perfection), begins to be promoted among Stoics, Pyrrhonists, Cynics as well as early Christian groups and Neoplatonics as a "regimen." ${ }^{55}$ Philosophers, as the Stoics, were motivated by the meaning of askesis and were inspired to maintain the component of minimalism in food consumption. Zeno's diet, for example, is simple and frugal:

\footnotetext{
${ }^{50}$ Finn Op 2009: 18.

${ }^{51}$ Finn Op 2009: 22.

${ }^{52}$ Ekhardt 2014: 265.

${ }^{53}$ Giangiulio 2016: 128 .

${ }^{54}$ Kouloumentas 2016: 250.

${ }^{55}$ The earliest theoretical treatments of asceticism as a regime comes in around the $1^{\text {st }} \mathrm{c}$. CE such as Discourse VI of Musonius Rufus and Discourse XII of Epictetus. Only much later the following enter the scene: Clement of Alexandria, Plotinus, Iamblichus, Porphyry, Proclus, Gregory of Nyssa, and Evagrius of Pontus.
} 
This man adopts a new philosophy,

He teaches to be hungry; nevertheless,

He gets disciples. Bread his only food,

His best desert dried figs; water his drink. (Diogenes Laertius, 6.24)

Musonius wrote that endurance of "cold, heat, thirst, hunger, meagre rations, hard beds" and "avoidance of pleasures" strengthened not only the body but also the soul, which was "trained for courage by patience under hardship and for selfcontrol by abstinence from pleasures" (Discourses, 6). The Stoic idea of "living according to nature" (D.L. 7.87) meant "living in harmony with one's own nature" if not one's consciousness and the "nature of the cosmos as a whole" (D.L. 7.87-88). "Living in accordance with nature" would mean maintaining "indifference to external goods" which was related to the idea that human life is unescapably subject to fate and external causes, so that the best way to endure these sources of subjection was by cultivating "indifference."

Porphyry writes of a tradition of intellectual argument against the consumption of luxury food, especially meat, among the Peripatetics, the Stoics and the Epicureans (De Abst. 1.3.3). The Epicureans indulge in a diet of "barleybread and fruit" (1.48.3). As Diogenes said, "thieves and fighters do not come from eaters of barley-bread; but informers and tyrants come from meat-eaters" (1.47.3).

Minimalism, by means of abstinence from meat, is prominently noticeable in the Middle Platonist philosopher, Plutarch. Plutarch appreciates the simple lifestyle when he refers to the Pythagorean ban on injury to animals which stretches as far as to plants (De sollertia animalium, 964e-f) and to Pythagorean Empedocles whose precepts were "law" for the ancient Greeks (De esu carnium, 2.3.998f-4.999a). The practice of bloodshed merges with the guilt of cannibalism by means of the concept of transmigration (1.996b-c) and the concept of the kinship of all living beings $(2.1 .993 \mathrm{~b}-\mathrm{c}, 2.7 .996 \mathrm{~b}-\mathrm{c})$. With the exception of the common Greek practice of consumption of meat (1.2.984f, 1.1.3.993b-6.995f) Plutarch admits that it is wrong that men consume the flesh of tame animals $(2.3 .994 \mathrm{~b}-\mathrm{c})$. Plutarch admits that the practice exposes "lawless conduct" $(2.997 \mathrm{~b}-\mathrm{c}) .{ }^{57}$ Plutarch and Porphyry share similar thoughts within their reference to the exploitation of animal life in some specific justified situations (likenecessity, hunger, scarcity of food or vegetable production). ${ }^{58}$

${ }^{56}$ Plutarch, On the Self-Contradictions of the Stoics 1037F; Cicero, On Moral Ends (De finibus) 3.4; Seneca, Moral Epistles, 95.7, 117.2, fr. 17.

${ }^{57}$ What Plutarch laments is the transformation from previously "lawful desires" when men depended on vegetable produce (De esu carnium, 1.2.993f-994b) to "unnatural and anti-social pleasures" (1.2.993d-e) which are certainly not in tune with human nature $(1.5 .995 \mathrm{a}-\mathrm{b}$ b-c; 1.6.995d-e e-f; 7.996a-b).

${ }^{58}$ Both philosophers deny exploitation of animal life on account of the human desire for luxury and variation of appetite: De Abst. 1.5, 2.27, 4.21 = De esu carnium, 1.4.994e-f; 2.1.9944-997a), 


\section{MINIMALISM: HEALTH AND NUTRITION}

When outlining a minimal diet for the philosopher, Porphyry reveals a substantial amount of familiarity with key perspectives related to a minimal diet in antiquity, such as nutrition and health. Porphyry explains: "One must safeguard health, not from fear of death, but so as not to be impeded in pursuit of the goods which come from contemplation. Health is best safeguarded by the undisturbed condition of the soul and the maintenance of thought directed to that which really is" (1.53.2); "Reduction of food also contributes to health" (1.53.4); Meat "does not conduce to health but rather impedes it" (1.52.1). However, "ordinary people think meat-eating contributes to health" (1.52.3). Health, Porphyry writes, will be maintained by a very light and fleshless diet (1.52.1). The masses, Porphyry clarifies, are not aware of the significance of health and nutrition, as they possess an "insatiable desire for life, wealth, money and fame" (1.54.3).

A minimal diet - a healthy diet - is prescribed not for the average individual but for the philosopher:

those who engage in banausic crafts, nor to athletes of the body, nor to soldiers, nor sailors, nor orators, nor to those who have chosen the life of public affairs' but to 'the person who has thought about who he is and whence he has come and where he should try to go, and who has principles about food, and about other proper behavior. (1.27.1)

The philosopher's food choice is limited to minimal portions and certainly not to the consumption of meat:

The contemplative holds to simplicity of lifestyle in both ways, for he knows the chains that hold him: he is incapable of reaching out for luxury, and he is content with simple things, so he will not seek to feed on animate creatures as if inanimate foods were not enough for him. $(1.56 .1)$

Porphyry does not find fault in the consumption of meat by such personalities as athletes, soldiers and those engaged in menial tasks (2.4.3). The nutritional value of meat, he says, aids the fulfillment of their goals. The philosopher, unlike the average individual or the athlete, is not in need of physical strength: "What the philosopher needs is not physical vigor but stamina, sustained endurance for the hard work of self-discipline and contemplation."

Porphyry explains that a simple diet is "easy to get" (1.49.4), "easy to prepare" (1.51.1), "inexpensive" (1.52.1). A simple and light diet is far better "for least disturbance comes from least" (1.50.3). Diverse food "not only fails

pestilence and war $(2.12,22,42,56-57=$ De esu carnium, 4.998b-c), diseases $(2.23,56=$ De tuenda praecepta, 8.126d-e; $15.129 \mathrm{f}-16.130 \mathrm{~b})$, destruction of dangerous animals $(3.20=$ De esu carnium $1.993 f-994 b)$. 
to relieve the troubles of the soul, it will not even enhance pleasure in the flesh" (1.51.5). A minimal diet "contributes to health" (1.53.4). Meat, after all, does not contribute to health but rather obstructs health. "Health is maintained by the same things through which it is acquired; and it is acquired by a very light and fleshless diet, so that must be how it is sustained" (1.52.1).

\section{LUXURY OF MINIMALISM}

In keeping with the by-gone tradition of minimalism which persisted in Roman society, in contrast to the tradition of imported luxuries and luxury foods made from imported ingredients among elite groups by the $2^{\text {nd }}$ and $1^{\text {st }}$ centuries BCE, Porphyry prescribes a meatless diet for the philosopher. Porphyry writes that in cities, where gluttonous obsessions with exotic foods persisted at an alarming rate, "riches and external and corporeal things were thought to be good and their opposites bad, and the soul is the least of their concerns" (2.43.2).

Porphyry dismisses the impact of luxury foods when he explains that it is the masses who are distracted by luxury. It is they who enjoy "rich, heavy foods" and are "carried away and by wanting it, they land in expense, illness, satiety or preoccupation" (1.53.4). The masses are not in the habit of observing minimalism when preparing food. When preparing a simple meal there will be no need of:

more servants; nor, when eating it, to reach out for more pleasures; nor, when getting full, to be filled with inertia; nor, when filled up with this heavy load, to become sleepy; nor, when full of the foods which fatten the body, to make one's chains stronger and oneself more inert and feebler about one's own concerns. (1.46.1)

One who maintains minimalism enjoys so many benefits:

A person who has accustomed himself to being satisfied with the minimum has got rid not just of one thing, but of thousands: excess of riches, the service of too many slaves, a mass of belongings, a condition of somnolence, intensity and frequency of illness, need for doctors, provocation of sexual desire, thicker exhalations, much residue, heavy chains, robustness which prompts action, an Iliad of evils. (1.47.2)

Porphyry recommends that the "need for more" ought to be removed, at least, as far as possible:

We must also make the body unaccustomed, so far as is possible, to pleasure from satiety, but accustomed to the repletion which comes from satisfying hunger; we must eat in order to get through everything, and must take as our limit not the unlimited, but the necessary. (1.54.5) 
When "one has fallen into extravagance, they say that one has a desire that is not necessary" (1.49.3). Dissatisfaction with life leads to need less so that nobody would want "silver tables and couches, perfumes and cooks and furniture and clothes and dinners" (1.55.3). Once the "need for more" is discarded the philosopher will be free to view things clearly:

Once the cause of needing many things has been removed, the excess of things brought into the body eliminated, and the weight of assimilated things lightened, the eye becomes free, anchored outside the 'smoke and swell' of the body. (1.46.4)

By maintaining minimalism the philosopher "will be genuinely rich" (1.54.6) as it is then that he "rejects unnecessary pleasures" (1.56.4) and will be "content with simple things" (1.56.1). Riches that are in accordance with nature, after all, are "limited and easy to get" (1.49.1). The philosopher abstains from the pleasures of the body and this is described as abstaining from luxuries, particularly from the luxury of a diet of meat: "The contemplative holds to simplicity of lifestyle in both ways, for he knows the chains that hold him: he is incapable of reaching out for luxury, and he is content with simple things, so he will not seek to feed on animate creatures as if inanimate foods were not enough for him" (1.56.1).

The type of "luxury" that arises from a simple lifestyle, says Porphyry, is far different from that of an expensive diet:

The pleasure experienced from luxury comes nowhere near the pleasure experienced from self-sufficiency; it is very pleasant to think just how little one needs. Take away luxury, take away sexual excitement and the wish for external recognition, and what further need is there for inert wealth, which is useful to us for nothing but only weighs us down? This is the way to be filled full, and the pleasure from this kind of satiety is unmixed. (1.54.4)

Meat-eating is not easier to provide than dishes of fruits and vegetables nor is meat cheaper to prepare than inanimate food. Meatless food is "pleasure-free and lighter on the digestion, less provocative of desires and less conducive to obesity and robustness" (1.46.2). Porphyry describes that "Reason," and nothing else will "reject abundant or excessive food, and will restrict what is necessary to a small amount" (1.46.1). A meat diet is viewed in contrast to the "luxury" of natural food:

But otherwise, insofar as one has fallen into extravagance, they say that one has a desire that is not necessary and does not arise by necessity from something that causes pain, but from something which causes distress or discomfort only by being absent, or else from delight, or wholly from empty and misleading beliefs; and such a desire does not refer back to any natural lack or to something which by its absence disintegrates the compound. (1.49.3)

For the philosopher, Porphyry recommends a minimal, simple and light diet (1.50.3). He believes that "almost every philosopher who puts frugality above extravagance would prefer the person content with little to the person who 
requires more" (1.48.1) and that by "controlling the body" the philosopher will "increase his inner good," the culmination of which is "his assimilation to the god" (3.26.13).

\section{CONCLUSION}

Porphyry's promotion of the component of minimalism as opposed to extravagance, in De Abstinentia, has so far not been assessed for its significant historical depth. Porphyry seems to be in favor of the prominent historical legacy of minimalism that goes back to the Archaic and Classical periods and evolves in the Republic and the early Empire. Even though this legacy had been tampered by a tradition of luxury dining, its effect has certainly flavored and served to signify an advanced stage of minimalism in Porphyry's prescription of a meat free diet for the philosopher in De Abstinentia.

\section{REFERENCES}

\section{Primary sources}

Arrian. Discourses of Epictetus, Books 1-4. Tr. by W. A. Oldfather. 1928. Harvard: Harvard University Press.

Atheneaeus. Deipnosophistes. Tr. by C. B. Gulick. 1927. Harvard University Press.

Cicero. On Moral Ends. Tr. By R. Woolf. 2001. Cambridge University Press.

Diogenes Laertius. Lives of the Eminent Philosopher. Tr. by R. D. Hicks. 1925. New York: Putnam. Herodotus. The Histories. Tr. A. de Selincourt. Ed. by A. R. Clay. 1954. Suffolk.

Musonius Rufus. Discourses. Tr. by C. E. Yale. Classical Studies 10. 1947. Yale University Press. Plutarch. On the Self-Contradictions of the Stoics, Moralia, Volume XIII: Part 2. Ed. by H. Chernise. 1976. Loeb Classical Library.

Plutarch. Moralia. Tr. by H. Cherniss and W. C. Helmbold. 1957. Harvard University Press. Porphyry. On Abstinence from Killing Animals. Tr. by G. Clark. 2014. London: Bloomsbury. Seneca. Moral Epistles. Tr. by J.W. Basore. Ed. by T.E. Page. 1928. London: William Heinemann. Suetonius. Gaius Caligula. The Lives of the Twelve Caesars. 1913. Loeb Classical Library.

Secondary sources

Bazant 1982: Bazant, J. 1982. "On the Gluttony of Ancient Greek Athletes.” Listy Filologické Folia Philologica vol. 105, no. 3, 129-131.

Beer 2010: Beer, M. 2010. Taste or taboo: Dietary choices in antiquity. Prospect Books.

Beerden 2018: Beerden, K. 2018. "Moderation, refined luxury, or extravagance? Fattened animals and ancient Roman norms and values." Food, Culture and Society vol. 21, no. 4, 505-520.

Brenk 2002-3: Brenk, F. 2002-3. "Sheer doggedness or love of neighbor? Motives for selfsufficiency in the Cynics and others." Illinois Classical Studies 27-8, 77-96.

Braund 1994: Braund, D. 1994. "The luxuries of Athenian democracy." Greece \& Rome vol. xli, no. 1, 41-48.

Bradley 2011: Bradley, M. 2011. "Obesity, Corpulence and Emaciation in Roman art." Papers of the British School at Rome 796, 1-41. 
Broekaert et al. 2016: Broekaert, W., Nadeau, R. and Wilkins, J. 2016. Food, Identity and CrossCultural Exchange in the Ancient World. Collection Latomus 354. Brussels.

Burton 1992: Burton, J.B. 1992. "The Function of the Symposium Theme in Theocritus' "Idyll" 14." Greek, Roman and Byzantine Studies 33:3, 227-245.

Ceglarska 2018: Ceglarska, A. 2018. "The Role of Myth in Political Thought." Krakowskie Studia z Historii Państwa i Prawa 11 (3), 343-355.

Clark 1999: Clark, G. 1999. Translate into Greek: Porphyry of Tyre on the New Barbarians in Constructing Identities in Late Antiquity. Ed. by R. Miles, 122-32. London-New York.

Clark 2005: Clark, G. 2005. "The health of the spiritual athlete.” In Health in Antiquity. Ed. by H. King, 216-29. London and New York: Routledge.

Clark 2007: Clark. G. 2007. “Augustine's Porphyry and the universal way of salvation.” In Studies on Porphyry. Ed. by G. Karamanolis, A. Sheppard, 13-27. London: Institute of Classical Studies, School of Advanced Study, University of London.

Dalby 1996: Dalby, A. 1996. Siren Feasts: A History of Food and Gastronomy in Greece. London.

Dalby 2000: Dalby, A. 2000. Empire of Pleasures. Luxury and Indulgence in the Roman Empire. Routledge.

Dalby 2003: Dalby, A. 2003. Food in the ancient world: from A to Z. Routledge.

DePalma 2001: DePalma, D. 2001. "Porphyry, Lactantius, and the Paths to God." Studia Patristica $38,521-28$.

Desmond 2005: Desmond, W. D. 2005. The Greek Praise of Poverty. Origins of Ancient Cynicism. Notre Dame, Indiana.

Dombrowski 1987: Dombrowski, D. A. 1987. "Porphyry and Vegetarianism: a Contemporary Philosophical Approach." Aufstieg und Niedergang der römischen Welt II 36/2, 774-791.

Ekhardt 2014. Ekhardt, B. 2014. "Bloodless Sacrifice: A Note on Greek Cultic Language in the Imperial Era." Greek, Roman, and Byzantine Studies 54, 255-273.

Finn 2009: Finn OP, R. 2009. Asceticism in the Graeco-Roman World. Cambridge University Press.

Gamlath 2018: Gamlath, I. 2018. “The Training of Porphyry's 'Athlete': The Ascetic Philosopher in On the Abstinence from Eating Flesh." Symbolae Philologorum Posnaniensium Graecae et Latinae 28 (1), 49-66.

Giangiulio 2016: Giangiulio, M. 2016. "Aristoxenus and Timaeus on the Pythagorean Way of Life." In Pythagorean Knowledge from the Ancient to the Modern World: Askesis, Religion, Science. Ed. by A. Stavru, A. Renger, 121-134. Wiesbaden: Harrassowitz Verlag.

Gildenhard, Viglietti 2020: Gildenhard, I., Viglietti, C. eds. 2020. Roman Frugality: Modes of Moderation from the Archaic Age to the Early Empire and Beyond. Cambridge University Press.

Gorman, Gorman 2014: Gorman, R. J., V. B. Gorman. 2014. Corrupting luxury in Ancient Greek literature. Ann Arbor. University of Michigen Press.

Hynek 2015: Hynek, B. 2015. Philosophy and Dietetics in the Hippocratic On Regimen: A delicate balance. Brill.

Johnson 2013: Johnson, A. P. 2013. Religion and Identity in Porphyry of Tyre: The Limits of Hellenism in Late Antiquity. Cambridge-New York.

Kouloumentas 2016: Kouloumentas, S. 2016. "The Pythagoreans on Medicine: Religion or Science?" In Pythagorean Knowledge from the Ancient to the Modern World: Askesis, Religion, Science. Ed. by A. Stavru, A. Renger, 249-262, Wiesbaden: Harrassowitz Verlag.

Lagia 2015: Lagia, A. 2015. "Diet and the Polis: An Isotopic Study of Diet in Athens and Laurion during the Classical, Hellenistic, and Imperial Roman Periods." In Archaeodiet in the Greek World: Dietary Reconstruction from Stable Isotope Analysis. Hesperia Supplement 49. Ed. by A. Papathanasiou, M. P. Richards, S. C. Fox, 119-145. Princeton, NJ : The American School of Classical Studies at Athens. 
Marx 2010: Marx, W. H. 2010. "High Priests of the Highest God: Third-Century Platonists as Ritual Experts." Journal of Early Christian Studies vol.18, no. 4, 481-512.

Meredith 1976: Meredith, A. 1976. "Asceticism Christian and Greek." Journal of Theological Studies 27, 313-332.

Notario 2013: Notario, F. 2013. "Cooking Pot as Melting Pot: Gastronomy in Late Classical Athens." In Sharing Cultures, Proceedings of the 3rd International Conference on Intangible Heritage. Ed. by S. Lira et al., 173-182. Barcelos.

Notario 2015: Notario, F. 2015. "Food and Counter-cultural Identity in Ancient Cynicism." Greek, Roman and Byzantine Studies 55, 583-607.

O’Meara 1982: O’Meara, J. J. 1982. "Indian wisdom and Porphyry's search for a universal way." In Neoplatonism and Indian Thought. Ed. by R. Baine Harris, 5-25. New York.

Olson, Sens 2000: Olson, S. D., Sens, A. 2000. Greek Culture and Cuisine in the Fourth Century $B C E$ : Archestratos of Gela. Oxford.

Osek 2020: Osek, E. 2020. “Agōn, Agonistic Imagery, and Agonistic Argumentation in Porphyry's De Abstinentia." In Conflict and Competition: Agon in Western Greece. Selected Essays from the 2019, Symposium on the Heritage of Western Greece. Ed. by H. L. Reid, J. Serrati, T. Sorg, 233-247. PParnassos Press.

Panagopoulou 2007: Panagopoulou, K. 2007. "Between Necessity and Extravagance: Silver as a Commodity in the Hellenistic Period." The Annual of the British School at Athens 102, 315-343.

Proctor 2014: Proctor, T. W. 2014. "Platonic Daemonic Trickery Mimicry: Traces of Christian Daemonological Discourse in Porphyry's De Abstinentia." Vigiliae Christianae 68, 416-449.

Schott 2005: Schott, J. M. 2005. "Porphyry on the Christians and Others: Barbarian wisdom, identity politics and anti-Christian polemics in the Eve of the Great persecution." Journal of Early Christian Studies 13, 277-314.

Totelin 2009: Totelin, L. M.V. 2009. Hippocratic Recipes: Oral and Written Transmission of Pharmacological Knowledge in Fifth- and Fourth-Century Greece. Brill.

Townsend 2011: Townsend, P. 2011. "Bonds of flesh and blood: Porphyry, animal sacrifice and empire." In Ancient Mediterranean sacrifice. Ed. by J. W. Knust, Z. Várhelyi, 214-31. Oxford.

Wecowski 2014: Wecowski, M. 2014. The rise of the Greek aristocratic banquet. Oxford.

\title{
THE PHILOSOPHER'S DIET IN PORPHYRY'S ON ABSTINENCE \\ FROM KILLING ANIMALS: CHARACTERIZING A HISTORICAL LEGACY OF MINIMALISM IN FOOD CONSUMPTION
}

\author{
Sum mary
}

Historical legacy, as an important constituent for the evaluation of the extent to which the past influences the present, sheds much light on some of the broader issues of the relation between the past and the present. One of the components of historical legacy is human food consumption habits. The domain of food consumption habits, in traditional Greek and Roman culture, contains a fairly noticeable diversity as it fluctuates between what seems to be two wide poles of dietary practices such as a simple diet, with the focus on minimalism and health and a luxury diet, with the focus on excess and extravagance. These poles, upon close analysis, have determined the dietary customs of antiquity while also formed a gastronomic identity. The impact of this historical legacy seems to have not only flavored Porphyry's discussion of the nature of the philosopher's diet in $O n$ Abstinence from Killing Animals but has also served in characterizing an advanced stage of minimalism in Greek and Roman food consumption habits. 